\title{
AN EFFECTIVE WAY TO MANAGE OVERHEAD COSTS IN THE CONDITIONS OF SERVICE UNITS
}

\author{
Petr Teichmann
}

\section{Klíčová slova:}

Activity-Based Costing and Management, analýza nákladů, náklady, obslužné útvary, procesní rízení nákladů, rozpočtování nákladů, režijní náklady, řízení nákladů

\section{Key words:}

Activity-Based Costing and Management, Budgeting, Cost Analysis, Costs, Cost Management, Overhead Costs, Service Units

\begin{abstract}
Abstrakt
Př́spěvek se zabývá řízením režijních nákladů v podmínkách obslužných jednotek, kde převládá režijní složka nákladů, a kde výstupem podniku není klasicky výrobek, nýbrž služba. Př́spěvek zahrnuje pohled na řízení nákladů z hlediska odpovědnostního i procesního a předkládá praktický návod na systematické řízení režijních nákladů v podmínkách obslužných útvarů.
\end{abstract}

\begin{abstract}
This paper is focused on cost management in terms of service units with dominating overheads. It contents aspects of both classical budgeting and cost analysis methods and cost management based on Activity- Based Costing methods. Its aim is to give a practical instruction how to manage overheads in service units.
\end{abstract}

\section{Introduction}

The basic objective of each enterprise is to achieve the highest possible margin on the invested resources, i.e., to deliver the existing volumes of services (earnings) with the lowest possible costs.

Today, when the competition is getting stronger, this objective can be ensured only by maximizing the focus on cost efficiency. It is generally known that the easiest way to earn a crown is not to spend that crown. For this reason a great emphasis is given on systematic work in the area of cost management.

This paper is focused on overhead costs management in the conditions of service units. In terms of the cost management service units (in particular repair and maintenance units, transport units and warehousing units, etc.) are different from standard production activities (where the enterprise repeatedly produces the same range of products) by the fact that the requirements for their services are very diverse, unpredictable and scarcely repeated in terms of content and scope. The situation is even more complicated by the fact that most cost items (in our experience) cannot be directly allocated to a particular job order.

A good example can be seen in case of fuel and personnel costs in railway transport. But these items represent the highest volume of the costs. These costs are then viewed as overhead costs and their management in real life is very difficult. 
While in production activities, according to Popesko [17, pg. 51], overhead costs represent 30 $-50 \%$ of the total costs (depending on their type) in case of service activities the overhead costs are significantly higher and their share may exceed $80 \%$ of the total costs. The experience shows the higher the share of overhead costs the more difficult to manage these costs.

In the current practice we can see two approaches to cost management. The first traditional approach examines the costs in their type classification following the line of responsibilitydriven management, i.e., budgeting and calculations including the following analysis of meeting or not meeting the preset budgets and calculations. This type of work with costs provides a picture about the level of the individual types of costs of a specific cost department of the company but it does not provide an answer why, where and in what stage of the production process these costs are created, how much the company actually has to spent on the individual activities and whether these activities are efficient.

However, these questions are answered by relatively new, untraditional approach to costs, i.e., Activity-Based Costing and Management.

The principle of Activity-Based Costing and Management (ABC) is based on allocating overhead costs to individual activities (processes) and because the cost objects (products, services) consume the activities priced this way (activities, processes), the costs of activities are further transferred (proportionately to the consumption of the activities) to the final objects (products, services).

This way overhead costs will become significantly more transparent and the causes of their creation and their size will be analyzed. Today the company management focuses more on reducing personnel and material costs because overhead costs represent the portion of costs that is very difficult to manage. This is caused mainly by an unclear relationship between the overhead costs and the services. In case of personnel and material costs the company management can estimate the impact of their change on services; however, in case of overhead costs these relationships with the application of the traditional management systems remain hidden. The managers by instinct are afraid to interfere with overhead costs because they are not certain what impacts these interventions will have on the services performed. Furthermore, the overhead costs and especially the costs of service units tend to inflate and grow on a long term basis [17, pg. 50] .

Another disadvantage of the traditional (responsibility-driven) way of management is that the company management will not know exactly what products are ultimately profit-making and which are loss-making (on condition that the product is not produced from start to end in one single cost center). Further, the company management will not know exactly the costs of the individual activities and whether these are efficient for the company or not. The answers to these questions can be provided by process analysis performed by the Activity-Based Costing method.

However, we cannot positively claim that it is necessary to depart from the traditional method of responsibility-driven cost management and to focus only on Activity-Based Costing as it is only the combination of both approaches appropriately designed and using the benefits of both approaches that will provide a comprehensive view of all aspects of cost management in a company. For example, responsibility-driven cost management in combination with a suitable motivation of the company management will help to keep the cost budget of the 
individual departments and at the same time activity-based cost monitoring will show the efficiency of the individual partial processes (activities) of the production process.

The aim of this paper is to show a comprehensive and mainly reliable method for overhead costs management in service units using both approaches.

\section{The current practice}

In the business practice we can see that the traditional approach to cost management, especially to their overhead components which is based on responsibility-driven approach, still predominates. This means that the company is internally divided into relatively small cost centers allowing separate monitoring of individual cost and revenues items.

These units prepare their annual budgets usually only to the anticipated (planned) capacity of the services. Subsequently they break down these budgets into months and quarters and evaluate the budgets not considering the level of the services generated.

This seems to be a mistake because overhead costs do not equal fixed costs and they are into a great extent depend on the services generated. And this is even more significant for the service units where it is very difficult to allocate most items to the specific job orders.

Payment of an incentive part of wages to employees in connection with the fulfillment of the cost budget is very rare in companies. But this material motivation is an excellent tool for maintaining or reducing the level of operating costs in the individual units.

Application of the process-driven approach to cost management is also very rare in business practice. But it is exactly this process-driven approach to cost management based on the Activity-Based Costing methods that is best for the companies where the overhead component of costs predominates because the basic principle of this method is to transfer the individual cost components from financial accounting through the related values down to the individual processes (activities). The company management will then get accurate information on the costs of a specific activity per year which helps the management to make a decision whether that particular activity should be developed or inhibited or possibly outsourced.

\section{Effective overhead cost management in the conditions of service units}

A system of overhead costs management which in the conditions of service units should provide a thorough view of costs, their mutual relationships and relationships with the achieved output must include a thorough cost analysis as well as their budgeting and process analysis.

\subsection{Cost analysis}

The objective of cost analysis is to get a detailed overview of the costs as a whole but also of the behavior of the individual cost groups or items and of their relationships.

The current trend is to work with costs in an isolated manner, i.e., without their relationship to the achieved output. But without this dimension it is possible to find out only their absolute level which does not tell us anything whether the money we spent on these cost types (items) were spent efficiently or not. If we monitor costs without their relationship to outputs then we 
lose the possibility to compare their efficiency in time. For example, if we compare the actual personnel costs without the relationship with the output achieved for the previous year with the personnel costs for the year before the last year we can only conclude that they either increased, remained the same or decreased. However, we are losing information that, for example, the volume of services significantly increased due to increased number of job orders that had to be covered by an increased number of hours generated. Or for example the volume of services decreased faster than wages, etc. However, if we compare wage demand (personnel costs/outputs) for the same time period then we will compare also the efficiency of wages paid.

\section{This means that the possibility of analysis of cost items in relation to outputs (revenues), i.e., their cost demand is a significant criterion for the selection of the methods.}

Specialized literature offers endless number of methods and tools suitable for cost analysis. But if we think about methods that would characterize the costs in relationship to the achieved outputs then the choice gets smaller.

Besides the known and commonly used methods such as the turning point analysis, safety margin, price sensitivity, fixed and unit variable costs it is advisable to include also the method of pyramidal breakdown of indicators into the annual analysis.

\subsubsection{Pyramidal set of indicators}

For the preparation of the pyramidal set of indicators of cost demands of the individual cost types we selected and modified method used by Synek [21, pg. 367] when examining the impacts on return of own capital during financial analysis. For the cost analysis we replaced the original indicators by groups of accounts as we know them from Czech financial accounting (50 - consumed purchases, 51 - consumed services, 52 - personnel costs, etc.). In order to allow for exact monitoring of development of the indicators in time (will be described later) and monitoring of the impact and the level of the individual items for $1 \mathrm{CZK}$ of the achieved output the pyramidal breakdown uses cost demands of these items (account/output e.g.,

$\frac{50}{\mathrm{v}}, \frac{\mathrm{si}}{\mathrm{v}}$ etc.).

The pyramidal set of indicators [22, pg.37] is based on a structure of a system of indicators where the more synthetic indicators are gradually broken down to products, fractions, sums or differences of partial indicators. The purpose of this gradual breakdown is a hierarchical arrangement of partial indicators in terms of their significance.

The pyramid enables to quantify the impact of partial indicators, including those that are considered as elementary, to a relative increment of the analyzed indicator. This fraction is marked as a partial relative increment (DRP) in \%, which in the product or fraction of partial indicators breaks down in the ration of logarithms of indices of partial indicators and in case of their sum it is broken down in the ratio of absolute increment of partial indicators. 
In our case the pyramidal set of indicators has the following form:

Figure 1 - Pyramidal breakdown of cost demands

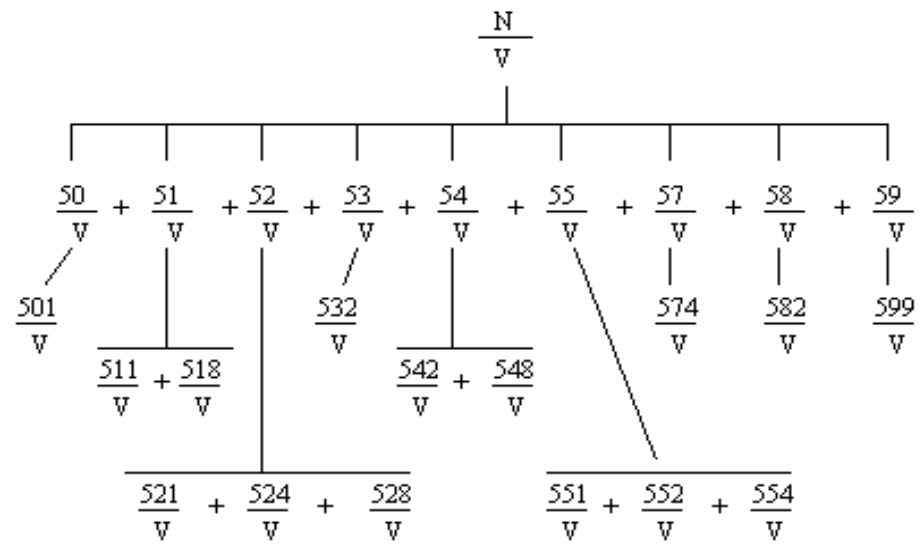

Source: modified according to Synek [22, pg.38]

When making the pyramid we record the following values in the individual fields:

- symbol of the indicator,

- value of the indicator in the basic period $\mathbf{A}$,

- value of the indicator in the current period $\mathbf{B}$,

- absolute increment of the indicator $\mathbf{B}-\mathbf{A}$,

- index of the indicator $\mathbf{B} / \mathbf{A}$,

- partial relative increment DRP.

Each field of the pyramid has the following shape:

Figure 2 - Pyramidal breakdown of indicators

\begin{tabular}{|c|c|}
\hline \multicolumn{2}{|c|}{$\begin{array}{c}\text { Symbol of the } \\
\text { indicator }\end{array}$} \\
\hline A & B \\
\hline B - A & B / A \\
\hline \multicolumn{2}{|c|}{ DRP } \\
\hline
\end{tabular}

Source: modified according to Synek [22, pg.38] 
Partial relative increment of the peak indicator is calculated as the percentage of the decrease (increase) of the indicator in the current period (B) against the value of the indicator in the basic period (A). This partial relative increment is subsequently broken down into lower indicators in the ratio of the absolute increments $(\mathrm{B}-\mathrm{A})$ of the partial indicators.

Pyramidal breakdown of cost demands, as indicated in figure 1, may be freely expanded or constricted as necessary or it is possible to add another stage of the breakdown when monitoring the cost demands of the individual accounts of the analytical records.

The clear advantage of this method is a detailed overview of the level and impact of the individual monitored cost items and the possibility to compare them in time.

The calculated values will give us a hint on what items we should be focusing during cost optimization. A disadvantage of this method is that it requires more work but this can be eliminated into a certain extent by using a suitable software, such as available MS Excel or MS Access.

The method of the pyramidal breakdown in combination with the analysis of turning point, safety margin, price sensitivity, fixed and unit variable costs will provide a comprehensive view of the costs as a whole and on their individual components in mutual relationships.

\subsubsection{Costs budgeting}

Another important aspect in working with costs is an aptly set up cost budgeting system. A viable option in practice was setting up an annual budget for overhead costs at a level of the anticipated (planned) capacity of outputs and its breakdown into the individual months and quarters. When evaluating the quarterly and monthly budgets it is very useful to convert these budgets to the achieved volume of outputs.

This conversion is an emphasis of the reproduction approach to overhead costs. [9 pg.66]. The identified level of the overhead costs can be imagined in such a way that the original share of the overhead costs "included" in the price of the corresponding output will return to the company so many times as the number of outputs produced or delivered to the customer.

By comparing the actually spent overhead costs with the fixed budget converted in a linear way to the actual volume of the activity the total (global) variance is identified, which in the subsequent steps is a subject of a more detailed analysis.

When the comparison respects the production volume impact then the identified global variance can be divided in two variances, i.e., consumer (economical) and volume (capacity) variance. However, a precondition for their identification is an existence (or at least a subsequent calculation) of a flexible (variable, alternative) budget. When setting up this budget the individual budget items are increased (decreased) proportionately to the fulfillment of the planned volume of services (capacity utilization) of the center while respecting the fixed or variable nature of the corresponding cost component. The calculated sum of the budgeted costs is equalized with the actual and the variance represents the so called consumer variance; the difference between the fixed budget converted in a linear way and the actual volume of the activity then expresses the volume variance. In general, each of these variances pertains to a different group of costs and expresses a different way of the propagated economics. The consumer variance is rather related to the variable component of the costs 
(even though we cannot exclude the possibility that it reflects a saving or exceeding of the so called avoidable fixed costs). It is a representation of the so called efficiency of the form (economics) and it is manifested in such a way that the saved or exceeded costs directly affect the level of available resources and profit of the company.

On the other hand the volume variance pertains to fixed unavoidable costs spent in connection with ensuring a certain capacity. It is an expression of the so called efficiency form of economics which is not manifested as an actual saving of the capacity costs but in that these costs can be "distributed" across a larger or smaller volume of outputs than expected. So this part of savings or overspending is not reflected directly in costs but it is reflected only subsequently in the revenues of the company when the corresponding outputs are sold.

For orientation in fulfillment of the costs plan it is advisable to monitor and evaluate the monthly and quarterly budgets in the cumulative way since the beginning of the year.

A budgeting system prepared this way is a very powerful tool for maintaining and gradual lowering of the budgeted costs in the individual internal departments (centers) of a company especially when the fulfillment of the overhead costs budget is connected with material incentives not only for the company management but for involved employees in the centers as well.

The described methods for cost analysis and budgeting provide an accurate and detailed overview of the size of the individual cost items, but we will not obtain more details why and where these costs are generated and with what activity of the company they are connected. This question may be answered accurately and reliably by a process analysis based of Activity-Based Costing.

\subsection{Process-driven cost management}

The previous part discussed costs in terms of their type and responsibility-driven management in the individual cost centers. In order to provide a comprehensive view of costs we will add a process-driven analysis based on the Activity-Based Costing method that does not deal only with costs in the individual cost centers but examines the costs for the individual processes (activities) performed across the departments of the company showing their efficiency in the full light.

A logical outcome of a process-driven analysis based on the Activity-Based Costing (ABC) method is the preparation of $\mathrm{ABC}$ calculations. Information from $\mathrm{ABC}$ calculations can be then used in the companies also for Activity-Based Management - ABM. After the implementation and mastering of the $\mathrm{ABC}$ method, this method may be expanded by its higher developmental stage - the Time Driven Activity-Based Costing (TD ABC).

\subsubsection{Activity-Based Costing}

Simultaneously with the overhead costs budgeting system for the individual departments it is possible to search for possible reserves in costs using the analysis of the individual processes (activities).

The aim of the analysis based on the Activity - Based Costing methods is to achieve distribution of overhead costs based on the actual causality of their creation [21, pg. 109] and 
to detect the causes of creation and magnitude of the costs connected with activities (processes) carried out across the organization departments. These activities are at the end connected with the offered output. The process-driven analysis is based on the assumption that processes consume resources and outputs consume processes.

A practical outcome of the process-driven analysis may result in preparation of ActivityBased Costing - ABC costing. As indicated by Popesko [17, pg.101], the basis of ABC costing is allocation of overhead costs to the individual performed activities through which they are then allocated to the individual cost objects. The procedure during $A B C$ costing consists of the following steps:

1. In the first step the spent economic resource, in this case an indirect cost is allocated to the individual activities defined; the allocation is done based on the reference value of the costs (Resource Cost Driver), which defined the way for the conversion of the costs from the accounting records to the individual activities defined.

2. In the second step the total costs for the individual activities (Cost Pool) are identified, the reference value of the activity or the Activity Cost Driver is defined and the costs for the unit of the activity are identified.

3. In the third step we identify the costs for the subject of the allocation, i.e., the cost object (output, service, and customer) on the basis of the costs for the unit of the activity and the volume of these units that are consumed by the objects of the allocation.

Schematically the ABC process may be illustrated as follows:

Figure $3-A B C$ costing

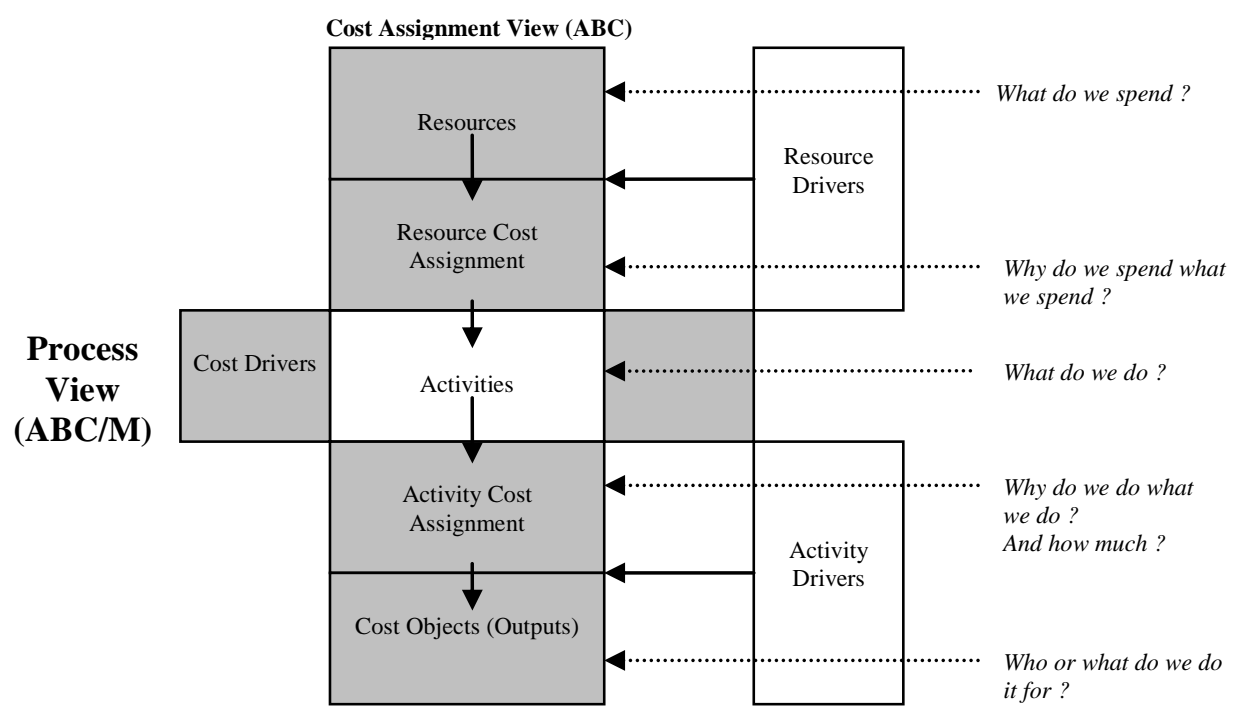

Source: adapted according to Cokins [1, pg.16] 
The vertical axis shows the flow of resources to the cost objects (activities consume resources and products consume activities). The horizontal line shows the process as a flow of activities. Before starting with the analysis we must identify the cost objects, i.e., the products or outputs on which we want to monitor the costs and we must map the company activities that generate overhead costs. When identifying the individual activities we will start with the logical arrangement of the processes that lead to the final product or service across all organizations departments (centers). When considering the number of the monitored activities and cost objects it is necessary to be aware of the efficiency and purpose of this system compared with the work demand for the evaluated data because process-driven cost management cannot be understood as a one-time preparation of $\mathrm{ABC}$ costing. This is a continuous process of repeated and consistent monitoring of costs for the individual processes (activities) and comparison of their development throughout the years.

For this purpose it is also necessary to adjust the number of the monitored activities and cost objects in connection with the information system used. For a medium size company it is reasonable to monitor $10-30$ activities [17, pg.120].

Each activity carries relationships that invoke creation of overhead costs. In case of service units these may be number of invoices, contractors, number of employees, hours generated, machine hours, material consumption, area, etc. And these reference quantities will be subsequently used for allocation of costs for the individual activities. A reference quantity represents a certain measure by which the output of the given activity can be measured. The selected reference quantity should capture the causal relationship of the costs to the output of the activity, but it should be selected in such a way that it is quantifiable on the basis of the data available inside the company, i.e., so that the data can be obtained. This ability to quantify or measure is necessary so that we are able to set the output measure, activity recovery rate - MVA. Basically this is defining the number of reference quantities which the given activity produced during the monitored period [17, pg.130].

Allocating the costs to the activities is the most important part of the process-driven analysis. The costs items that have direct relationship with the activities will be allocated to the individual activities directly; other allocated costs will be allocated with the use of reference quantities.

When defining and quantifying the reference quantities we use specific data that we have available. If in the given moment we do not have accurate data available for the beginning we can use expert estimate. But after some time, monitoring of data for the reference quantities should be supported by the database of the applied information system.

When allocating the data to the activities the following formula must be observed:

$$
N=\sum(p * N / P)
$$

in which

$\mathrm{N}=$ total cost for the item

$\mathrm{p}=$ number of the outputs in the activity

$\mathrm{P}=\quad$ total number of outputs

Before the allocation of costs to the activities it is advisable to check the relationships between the reference quantities that we selected and the corresponding items of the budget.

For the test we will use linear regression analysis in which the strength of the dependence of the reference quantities and the budget items is given by the determination coefficient $r 2$ [14, 
pg. 140]. The determination coefficient specifies what part of variability of dependant variable $y$ is explained by the regression. For the analysis I recommend selecting the data on the actual spending of the individual budget items over a longer period of time ( 5 and more years) and the reference quantities values in the same time sequence. Independent variable $x$ is made by the reference quantities values and dependent variable $y$ is made by the data on spending of the individual budget items.

The analysis can be prepared using the statistical functions in MS Excel or by using numerous available statistical freeware (e.g. program R).

The results of the regression analysis will then show whether the reference quantities were selected correctly.

After allocating the costs to the activities we will compare the costs of the activities with the total achieved revenues. The obtained haler index expresses the demand factor of the activity per $1 \mathrm{CZK}$ of achieved outputs (revenues). By this index we can compare the cost demands of the activities among themselves as well as in their development in time.

Although the identification of costs for activities is only a partial step of the process-driven analysis, it is also an excellent tool for evaluating the efficiency of the activity performed.

After allocating the costs to the activities we will transfer the costs of the activities to the cost objects using the reference quantities again. This time these will be reference quantities (Activity - Cost Drivers) expressing the relationship of the activity to the cost objects. For service units it most likely will be the time of duration of the activity necessary for delivering the examined output (cost object).

If in the previous stages of the creation of the $\mathrm{ABC}$ system we managed to identify the costs of the individual activities and the output measure we can now proceed to calculating the unit costs of the activities (activity primary rate) marked as JNA. The value of the activity primary rate shows what level of costs is connected with output of one unit of the given activity. The activity primary rate (JNA) can easily be quantified as a fraction of total activity costs (CNA) and the activity output measure (MVA):

$$
J N A_{i}=C N A_{i} / M V A_{i}
$$

The activity primary rate represents an intermediate stage in the conversion of costs to the cost objects. While the total costs of the activities provided only information on the cost demands of the carried activities, the unit cost can be used relatively easily for the conversion of the total overhead costs to cost objects on condition that we are able to quantify the number of units of the reference quantities consumed by the individual cost objects [17, pg.133] and prepare $\mathrm{ABC}$ calculations for each selected cost object.

\section{Generalization of the cost management methodology in terms of service units}

Reflecting the situation in the Czech enterprises focusing of services as it is described in point 1 and the methods described above, we can offer a general methodology suitable for overhead 
costs management in service units where the output of the effort is a diversified service that is only rarely repeated with respect to its type and scope.

The common feature of the current overhead costs management in these companies is usually narrowing of the attention only to the overhead costs disregarding the achieved outputs. Therefore, for these purposes we selected methods that will provide a comprehensive view, i.e., they will not analyze only the costs alone but they will analyze mainly their relationship with the achieved outputs.

Specialized literature offers either a standard approach to costs based on responsibility-driven cost management (Král, Fibírová etc.), or newer methods that are based on process-driven cost management (Cokins, Kaplan, Anderson, Popesko, Staněk, Petř́k etc.).

With respect to the diversity of the business practice we unequivocally recommend as the most efficient such cost management that combines both of these aspects.

For this reason the cost management methodology described below combines the strengths of both approaches, i.e., the responsibility-driven cost management as well as the methods that are based on the process-driven cost management.

The practical analysis of this methodology assumes introducing elementary features of the responsibility-driven cost management, i.e., dividing the department into logical units (centers) allowing individual monitoring of the individual items of costs and revenues.

The application of the recommended cost management method may be divided into 3 steps:

1. cost analysis,

2. cost budgeting and evaluation of the budgets reflecting motivation of the employees,

3. preparation of $\mathrm{ABC}$ calculations and their practical application.

\section{1st step - cost analysis}

The objective is to obtain an accurate view of the total costs, but also of the magnitude and importance of the individual cost items and to identify their relationships with the total achieved output.

For this analysis we can use the break-even point analysis as well as analysis of safety margin, price sensitivity, fixed and unit variable costs. To obtain a comprehensive view of the costs it is desirable to include in the analysis also the method of pyramidal breakdown of indicators.

The method of pyramidal breakdown of indicators will provide a detailed overview on the development of the individual cost items and their relationship to $1 \mathrm{CZK}$ of the achieved output. This method is described in detail in point 2.1.1. As an option, instead of the data of two years it is possible to compare the annual budget with the actual data.

Using the analysis of turning point and safety margin we will check the reasonability of the fixed costs in relation to the unit price and the output volume.

We will carry out this analysis at least once a year, preferably before the preparation of the annual budget, and we will incorporate the results to the planned budgets. 
It is possible to apply a whole range of other solutions but it is necessary to consider the demand factor of their routine application.

\section{2nd step - budgeting of the overhead costs and evaluation of the budgets in relation to the material motivation of the employees}

After the preparation of the annual budget and its approval by the management we recommend breaking this budget down into the individual quarters and months.

When evaluating the quarterly and monthly budgets, these budgets will be converted based on the actual achieved outputs and the economic and volume variance will be evaluated (see point 2.1.2). For intelligent cost management and orientation in the fulfillment of the cost budget it is desirable to monitor and evaluate the quarterly and monthly budgets in a cumulative way year-to-date.

Such budgeting system is a very powerful tool for maintaining and gradually reducing the budgeted costs in the individual internal departments (centers) of the company especially when fulfillment of the cost budget is connected with material motivation not only for the management but also for the individual employees in the centers.

\section{3rd step - preparation of ABC calculations and their practical application}

Simultaneously with the system of budgeting of overhead costs we are also searching for possible reserves in the costs using the analysis of the individual processes (activities).

When defining the individual activities we will start with the logical arrangement of the processes resulting in the final product or service across all organization departments (centers). However, when specifying the quantity of the monitored activities it is necessary to consider the efficiency and expediency of this system compared with the demand factor of the data evaluation.

Process-driven cost management cannot be understood only as a one-off preparation of $\mathrm{ABC}$ calculations. This is a continuous process of repeated and continuous monitoring of costs of the processes (activities) and comparing their development throughout the years.

This needs to be reflected also in the quantity of the monitored activities and the cost objects in relation to the used information system. For a medium size company it is reasonable to monitor $10-30$ activities.

Cost allocation to activities is the most important part of the process analysis. Those cost items that have a direct relationship with the activities will be allocated to these activities directly; other allocable costs will be allocated using reference values.

When defining the reference quantities we use specific data that we have available. If in the given moment we do not have accurate data available for the beginning we can use expert estimate. But after some time, monitoring of data for the reference quantities should be supported by the database of the applied information system. In the initial specification of the reference quantities we will check their relationship with the individual cost items in time sequences for $5-10$ years using statistical methods. A suitable tool is a linear regression analysis with a determination coefficient (see point 2.2.1). The analysis can be prepared using the statistical functions in MS Excel or by using numerous available statistical freeware program R. 
After allocating the costs to the activities we will identify the demand factor of the cost objects (i.e., the cost objects for which we want to monitor the costs) for consumption by the activities and subsequently we will transfer the costs of the activities using the reference quantities of the activities to the cost objects.

\section{Conclusion}

The objective of this paper is to assist the management of service units in their uneasy task of overhead cost management. For this reason I have selected from both approaches to overhead cost management (the responsibility-driven and the process-driven approach) those methods that as a whole will help to optimize the level of overhead costs.

Cost analysis using the method of pyramidal breakdown in combination with analysis of turning point, safety margin, price sensitivity, fixed and unit variable costs will also provide a comprehensive and detailed view of their individual components, of their development in time and their mutual relationships and connections between them but mainly of their relationship to the achieved outputs.

Using the above mentioned method for cost budgeting in connection with material incentives of the employees we will get another powerful tool for a gradual reduction in budget costs and the process-driven analysis will show the efficiency of the individual activities in the full light. The quantified costs for the process (activity) are an excellent tool for searching for internal reserves and they are a good foundation for a decision whether it makes sense to perform the given activity or whether it is better to think about outsourcing.

Practical application of the aforementioned method for overhead cost management in service units is not very labor intensive and it does not require support of a new specialized software. Everything can be managed with the existing information system with the current staff. If this activity becomes a regular routine the reward for the increased work load will be a reliable management of operating costs that ultimately will also result in their significant savings.

\section{Literature:}

[1] COKINS, G. Activity-based Cost Management Making it work: A manager's guide to implementing and sustaining an effective ABC system. Chicago: Irwin, 1996.

[2] COKINS, G. Activity-Based Cost Management: An Executive's Guide. John Wiley and Sons, 2001. ISBN 047144328X.

[3] DRURY, C. Management and Cost Account, Fifth Edition, Thomson Learning: 2001, ISBN 1-86152-536-2.

[4] ESCHENBACH, R. Controlling. Edited by Stefan Güldenberg - Werner Hoffmann, Translated by Pavla Fialová - E.2nd edition. Praha: ASPI, 2004. 814 p. ISBN 807357-035-1.

[5] FIBÍROVÁ, J., ŠOLJAKOVÁ, L. a WAGNER, J. Nákladové a manažerské účetnictví. 1st edition. Praha: ASPI, 2007. 230 p. ISBN 978-80-7357-299-0.

[6] GLAD, E. and BECKER, H. Activity-Based Costing and Management. John Wiley and Sons, 1996. ISBN 0-471-96331-3.

[7] HINDLS, R., HRONOVÁ, S., SEGER, J. a FISCHER, J. Statistika pro ekonomy. Praha: Professional Publishing, 2002. 420 p. ISBN 978-80-86946-43-6.

[8] HINDLS, R., HRONOVÁ, S. a NOVÁK, I. Analýza dat v manažerském rozhodování. Praha: Grada Publishing, 1999. 360 p. ISBN 80-7169-255-7. 
[9] HRADECKÝ, M. a KRÁL B. Řizení režijních nákladi̊. 1st edition. Praha: Prospektum, 1995. 96 p. ISBN 80-7175-025-5.

[10] INNES, J. and MITCHELL, F. Practical Guide ToActivity-Based Costing, Kogan Page: 1998. ISBN 0749426209.

[11] JACOBS, F., MARSHALL, R. and SMITH S.: An alternative method for allocating service department cosi, Ohio CPA Journal, Apr 1993, 52,2, ABI/INFORM Global s. 20.

[12] KAPLAN, R. S. and COOPER, R.: Cost and Effect: Using Integrated Cost Systems to Drive Profitability and Performance, Harvard Business School Press, 1998, ISBN 0875847889.

[13] KAPLAN, R. S., ANDERSON, S. R. and STEVEN, R. Time-Driven Activity - Based Costing: a Simpter and More Powerful Path to Higher Profits. Boston: Harvard Business School Press, 2007.

[14] KAPLAN, R. S. and JOHNSON, J. Relevance Lost-The Rise and Fall of Management Accounting. Boston, Harvard Business School, 1986.

[15] KRÁL, B. Manažerské účetnictví. Praha: Management Press, 2006. 624 p. ISBN 807261-141-0.

[16] PETŘÍK, T. Procesní a hodnotové rízení firem a organizací - nákladová technika a komplexní manažerská metoda ABC/ABM (Activity-based Costing, Activity-based Management). Praha: Linde, 2007. 911 p. ISBN 80-247-1046-3.

[17] POPESKO, B. Moderní metody ř́zení nákladi̊. 1st edition. Praha: Grada Publishing, 2009. 240 p. ISBN 978-80-247-2974-9.

[18] PORTER, M. Konkurenční strategie. 1st edition. Praha: Victoria Publishing, 1994. 403 p. ISBN 80-85605-11-2.

[19] SCHROLL, R. a kol. Manažerské účetnictví v podmínkách tržního hospodářství. 1st edition. Praha: Trizonia, 1993. 255 p. ISBN 80-85573-23-7.

[20] STANĚK, V. Zvyšování efektivnosti procesním ř́zením nákladi̊. Praha: Grada Publishing, 2003. 236 p. ISBN 80-247-0456-0.

[21] SYNEK, M. a kol. Manažerská ekonomika. 2. přepracované a rozšířené vydání. Praha: Grada Publishing, 2000. 475 p. ISBN 80-247-9069-6.

[22] SYNEK, M. a kol. Manažerské výpočty a ekonomická analýza. 1st edition. Praha: C. H. Beck, 2009. ISBN 978-80-7400-154-3.

[23] VOLKAN, I.: ABC \& ABM - The couple which prevails cost calculation and modern administrativ for performance, Journal of Accounting and Management Information Systems, $2^{\text {nd }}$ International conference AMIS 2007, Academy of Economic Studies, Bucharest, 2007, ISSN 1583-4387.

JEL D24, M41, M21

\section{Ing. Petr Teichmann, Ph.D.}

Faculty of Economics

VŠB - Technical University Ostrava

17. listopadu 15/2172, 70833 Ostrava - Poruba

pteichmann@ms-us.cz 